\title{
Intertextuality as a Postmodern Narrative Strategy in the Novelette "The Burning War of the Mind" by Tolen Abdikov
}

\author{
Alla Abdrakhmanovna Dzhundubayeva ${ }^{1}$ \\ ${ }^{1}$ Kazakh National Pedagogical University n. a. Abay, Almaty, Kazakhstan \\ Correspondence: Alla Abdrakhmanovna Dzhundubayeva, Almaty, Nauryzbai batyr, 49/61, 76. 050000, \\ Kazakhstan. Tel: 7-727-278-0745; 7-701-725-4705. E-mail: alla_1376@mail.ru
}

Received: March 19, 2015 Accepted: April 21, 2015 Online Published: May 14, 2015

doi:10.5539/res.v7n7p296 URL: http://dx.doi.org/10.5539/res.v7n7p296

\begin{abstract}
The article researches the novelette "Parasat Maydany" by the Kazakh writer T. Abdikov in its Russian version - "The burning war of the mind"- one of the best examples of the national literature of Kazakhstan of the first decade of this century. The aim of the study is to determine the role of intertextuality in the discourse of the writing as a narrative strategy for translation of the authorial intention and reflection to the reader through a combination of "own" and "foreign" words in the text. The main research method is narratology, particularly its contemporary theoretical developments in the field of communication strategies of the narrator with the narratee directly in the text, and the author with the reader-by means of the text. Individual approaches of receptive aesthetics and cognitive literary studies were also used for understanding the internal motives of the protagonist of the novelette, finding some mechanisms to influence the reader and to predict the reader's reception on intertextual inclusions in the writing. The study revealed features of the narrative structure of the novelette, representing the strategy of intertextual games with the reader as a way for the author to interact with the reader by encoding intertext semantics of the writing and its desired decoding by the reader.
\end{abstract}

Keywords: intertextuality, narratology, narrative strategies, narrator, intrigue

\section{Introduction}

The subject of this study was the novelette "Parasat Maydany" by the Kazakh writer T. Abdikov in its Russian version - "The burning war of the mind" (Abdikov, 2007) - translated by the famous Russian writer Anatoly Kim. In 2003, the novelette was awarded by the International Literary Franz Kafka Prize, and in 2004 - by the State Prize of the Republic of Kazakhstan, in connection with which this research is important and relevant, both in line with Kazakh literature, and in the context of the world of literary criticism as a whole.

The novelette is studied in terms of narratology, particularly from the point of view of the problem of intertextuality, or "the text in the text", as the realization of narrative strategies of interaction of the author with the reader, based on a combination of "own" and "foreign" words in the writing. The methodological basis of the study was the works by M. Bakhtin, R. Barthes, I. Ilyin, V. Schmidt, V. Tyupa and other contemporary scholars of narratology.

In addition, given that the number of researchers call the interaction of the author with the reader as "cognitive phenomenon" (Shunikov, 2006), the research also involved some approaches of cognitive literary criticism and receptive aesthetics.

\section{Materials and Methods}

\subsection{The Concept of Intertextuality in Literature}

The concept of intertext is closely linked with the concept of intertextuality-the term introduced, as it is well known, by Yu. Kristeva, based on the theory of dialogueness by M. Bakhtin. The canonical formulation of the concept of "intertext", by remark of Ilyin (1996, p. 227), was given by R. Barthes: "Every text is an intertext; other texts are present in it at various levels in more or less recognizable forms: the texts of preceding cultures and the texts of the surrounding culture. Each text is a new fabric woven from old quotes. Fragments of cultural codes, formulas, rhythmic structures, fragments of social idioms, etc. - all of them are absorbed by the text and mixed in it, because the language exists prior to and around the text. As a prerequisite for any text, intertextuality cannot be reduced to the problem of sources and influences; it is a common field of anonymous formulas, the 
origin of which is rarely to be found, unconscious or automatic citations given without the quotation marks" (Barthes, 1973, p. 78).

Fruitful for our study was the identification of intertextuality by E. A. Tsurganova: "Intertextuality means the "intertextual interaction, correlation with other specific text where each text is seen as the result of assimilation and transformation of another text, as a part of the "cultural text". Specific forms of intertextuality are the borrowings and processing the themes, direct or hidden citation, plagiarism, allusion, retelling, imitation, etc." (Tsurganova, 1990).

I. P. Ilyin speaks of intertextuality as a key sign of postmodern text, intertextual interaction which leads to the so-called intertextual game, and "in the course of reading this text, all the three: the author, the text and the reader - are transformed into a single" (hereinafter Ilyin quotes L. Perron-Muazes) "infinite field of play for the writing" (Ilyin, 1996, p. 226). In other words, the intertextual game becomes the main strategy of the postmodern paradigm, which aims to involve the reader actively in the process of decoding the meanings hidden in the intertext.

In our opinion, the novelette "The burning war of the mind" demonstrates a game designed for quotational consciousness of the reader, capable to solve the codes out by the author into the intertext.

\subsection{The Concept of "Narrative Strategy" in Modern Literary Criticism}

The term of "narrative strategy" is relatively new in literary criticism, and its clear definition has not yet emerged in science. The history and development of this concept is told by G. A. Zhilicheva: "The term of "narrative strategy of a novel" was first proposed by J. Souvage. W. Booth, in the analysis of different types of narrator, pointed out the ways of "explication of the narrative strategy"... J. Williams uses the term of "strategy", referring to the narrator projecting of the reader, and modelling the reception. M. Yang proposes to name the narrator's methods as a strategy: his "personalization" or "concealment". P. Ricker, talking about the methods of "integrating dynamism" in the narrative, speaks of "...the ability of the narrative" to express its object through narrative strategies that generate original holistic formations. Most often the term is used to refer to the uniqueness of a particular text (Zhilicheva, 49).

However, V. I. Tyupa gives the most complete characterization of this concept, in the opinion of many modern scholars: "The narrative strategy consists in the positioning of the verbal subject (the narrator) by the cognitive subject of communication (the author) with respect to the objects and recipients of storytelling" (Tyupa, 2011, p. 8). Hence, the narrative strategy of his theory is a "configuration" of three selective points, mutually causing each other:

1) A particular narrative picture of the world (reference competence of the author);

2) A narrative modality (creative competence of the narrator, storyteller, chronicler);

3) A narrative intrigue (receptive competence of the addressee)" (Tyupa, 2011, p. 9).

Productive one became the definition by O. A. Kovaliov: "The concept of "narrative strategy", similarly to the term of "the strategy of the text" implies a certain idea of the author about his reader; and through a literary text, the author tries to achieve some of the goals; he uses a variety of methods of influence for the sake of achieving them" (Kovaliov, 2009, p. 39).

In our work, this strategy of the author's impact on the reader is the intertextuality.

\section{Results}

\subsection{The Role of Intertextuality in the Narrative Structure of the Novelette by T. Abdikov}

\subsubsection{Features of the Narrative Structure of the Novelette "the Burning War of the Mind"}

One of the main artistic features of the researched novelette is the extensive intertextuality, whose role in the structure of the writing will be revealed in the course of our analysis. However, despite the presence of a "foreign" word in the text by T. Abdikov, his novelette is unique, both in terms of narrative structure, and from the point of view of the author's intention.

The author creates an intermediary between the protagonist and the reader - the primary narrator (Schmid, 2008, p. 80), introducing to the reader the diary of the protagonist and acting as a narrator of as if framing story. The protagonist of the main novelette thus becomes the secondary narrator, though he is the author of the diary.

Let us refer to the text (text in italics is by T. Abdikov- $A$. D.):

"A doctor whom I know gave me the diary. By the way, the author of the diary was also an old friend of mine.... 
It seems that the author of the notes still assumed that someday they would fall into someone's hands and attract the attention of another soul. ... Providing the name of the author of the notes would probably inappropriate. We assume that it is one of the many unknown of our contemporaries, one of those who lives near us, not revealed at their innermost essence" (Abdikov, 2007).

Here is a fragment of the first diary entry by the protagonist:

"March 13

It seems that something has changed in my life. ... Maybe I lost nerves, there is no order in thoughts, I forget what I was just thinking about... Moreover, the diary -it contains records as of March 3, and the next, as of March 4, 5 and 6, are missing for some reason. Only on March 7, they were resumed. What I was doing on the missed days - I do not remember for the life of me" (Abdikov, 2007).

As we can see, from the very beginning the intrigue is declared, which is associated with the omission of some days of life in the protagonist's mind. This element of postmodern games with the reader, firstly, creates intrigue in the text, and then becomes the key to its disclosure. It becomes more apparent with the appearing of another narrator:

"March 25

In the morning, intending to take the medicine, I reached for a glass of water standing on the bedside table, and suddenly saw a piece of paper folded into four. ...

There is something familiar in the handwritings, as if it belongs to a person whom I once knew. ... ... "My unknown friend! First, take my excuses! Without your knowledge, I read your diary. But reading it involuntarily made me take up to write this letter. You literally forced me-led to the most profound reflections, the inner dialogue with you. ...

Let us reveal souls to each other! ... Please make up your mind to write me a reply-put your letter into the bottom drawer of the table in the hallway.

Your anonymous peer"

(Abdikov, 2007).

Changing the standard font to italics marks the transition from one narrator to another, i. e., the appearance of a stranger's letter shall indicate the presence of the tertiary narrator in the novelette. As it will be further revealed, it is the uncontrolled second "I" of the protagonist, the "dark" side of his personality, his counterpart-antipode. For convenience, let us call the secondary narrator, representing the "light", recognized by the protagonist side of his personality, as the main narrator, and his imaginary opponent, created by him, but at the same time rejected as the narrator-simulacrum. The appearance of this type of narrator is characteristic of postmodern narrative structure of the text, when the reader is puzzled: "Who is speaking?"

With the emergence of the discourse from the tertiary narrator, the problem of the good and the evil, the main in the writing, comes to the fore. An attempt to solve it is distributed between the main narrator and the narrator-simulacrum. The first proclaims the priority of the good, the second-the power of evil, while emphasizing the duality concepts of the "good" and the "evil": "The main thing is that the notorious Good and Evil-like Siamese twins, are inseparably fused with each other and cannot exist without one another" (Abdikov, 2007).

Thus, the interaction of the two narrators, the written dialogue between them is used to make up the main intrigue of the writing, which the author, playing with the reader, does not reveal until the ending of the novelette. At that, from the first page, an attentive reader will find a number of hints for penetration into the author's intent. Thus, one of them pointing to an unhealthy mental state of the protagonist becomes the dream in which we find the intertextual correlation with the writings by N. V. Gogol and F. M. Dostoyevsky:

"March 26

Something is bad with me. I had a bad dream last night. I was going down the dark corridor, light bulbs were off. ... I was moving on the touch. ... Suddenly, something sharp slashed my neck. ... I gently sat in the armchair. Then, having decided, I abruptly pulled the head completely. I put it aside on a nearby armchair. ... It seems I had to be in a hurry. What should I do now? Headless ... I gently lift the edge of the newspaper and see - see! - that it lies in place. I ought to get rid of it soon... Here I am suffering, sitting in place — until I wake up" (Abdikov, 2007).

Moreover, if this fragment shows the psychological problem of the protagonist metaphorically, then below it is 
described quite clearly:

\section{"March 27}

What could be worse when the person starts to fear himself? Your inner world becomes wild and incomprehensible as a creepy forest where you got lost. ... Suddenly you feel that you do not exist and it is somebody else who wanders in the wilds of the dense forest. You have become a stranger, an outsider in relation to yourself. ...

After dinner, I went for examination to the doctor. ... He read a lecture on psychopathology. Particularly he focused on the split personality" (Abdikov, 2007).

It seems to us, that the essence of the protagonist's madness indirectly voiced here is not that clear. His illness - split personality — is not only and not that much physical, a psychological disease of a specific person, but an allegory of spiritual discord with inner self of a modern man in general, fighting own light and dark sides, reflecting the eternal struggle between the good and the evil, the black and the white, the faith and the unbelief. But apart from this problem, traditional to the world literature, the protagonist's disease in this case is explained, in our opinion, purely as a "postmodern sensibility", which I. P. Ilyin characterizes as follows: "The specific vision of the world as a chaos, devoid of cause-and-effect relationships and values, the "decentred world", appearing to consciousness only in the form of hierarchically disordered fragments" (Ilyin, 1996, p. 205).

Moreover, the world around us, seen by the protagonist, is exactly as such—deconstructive and full of chaos:

"March 15

Long time ago I quitted reading newspapers. One man raped and killed his mother. Another man raped and kill his daughter. That girl killed and threw her new-born child on the scrapyard. A millionairess married her son. A maniac was killing people and eating their flesh. A man officially married another man. A necrophile copulated with cadavers" (Abdikov, 2007).

In a situation of such demoralization of the society, it is difficult to a person to determine a landmark in life, to find the purpose of life and to save it. Moreover, the madness in this case looks like a natural, logical, and almost inevitable finale of the development of a modern individual. An important element in the disclosure of the problem in the novelette is intertextuality, which provides communication between the narrator and narratee (the protagonist acts in both roles by turn), as well as between the author and the reader. Let us consider the intertextual fragments in the writing.

\subsection{The Value of Intertextuality in the Epigraph of the Novelette}

Intertextuality in the novelette reveals itself from the first row of the writing. Thus, the epigraph is the Hamlet's soliloquy by W. Shakespeare:

To be, or not to be, that is the question-

Whether 'tis Nobler in the mind to suffer

The Slings and Arrows of outrageous Fortune,

Or to take Arms against a Sea of troubles,

And by opposing, end them? To die, to sleep

No more - and by a sleep to say we end

The heartache and the thousand natural shocks

That flesh is heir to-

'tis a consummation

Devoutly to be wished! To die, to sleep (Abdikov, 2007).

and the aphorism by Robert Penn Warren:

"You have to do good out of evil,

because it can be done out of nothing else" (Abdikov, 2007).

In this case, we observe an intertext as a direct quotation. The author's appeal to the classics, firstly, denotes deep and broad context of the problem of the good and the evil in the world literature, secondly, he embeds his writing in that context as part of the "great intertextuality" (Ilyin, 1996, p. 226).

In addition, both epigraphs to the novelette represent the problem of internal discord of a person, search for 
oneself and the meaning of own life, and, hence, in turn, there is a motif of duality, the most famous in the world literature from the writings by F. M. Dostoyevsky, and the main one, as has been shown, in the novelette by T. Abdikov.

\subsection{Russian Classical Intertext in the Novelette}

As we shall see further, intertextual correlation with the writings by F. M. Dostoyevsky passes through all the writing by the Kazakh writer and advocates as a kind of "intertextual authority" (Ilyin, 1996, p. 191) for it.

However, the context of Russian literature in the novelette is presented not only by the name of the great Russian writer. Thus, the form of diary entries, creating the illusion of credibility for the reader and the reality of the described events, refers, in our view, to the "Diary of a Madman" by Gogol (1984), the "Dream of a Ridiculous Man" by Dostoyevsky (1982) and the "Diary of a Madman" by Tolstoy (1982).

First, all of these works are connected by the theme of madness, somewhere imaginary somewhere real, but in all cases being the cause of the internal conflict of the protagonist. This causes the narrative peculiarity of all these texts: the narrative in them comes in the first person, as if by the protagonist himself, or, using the terminology by Schmidt (2008, pp. 70-90)—on behalf of the personal explicit narrator, i. e. narrated and narrating "I" are the same (Schmidt, 2008, pp. 92-95).

Let us turn to the specified text in the history of their creation and show in detail, how the theme of madness of the protagonists, becoming the leitmotif of intertextual between them, developed in them at the level of narrative.

\section{The "Diary of a Madman" by N. V. Gogol}

First, the relationship between these writings is found at the level of the structure - the diary of the protagonist. However, if the dates in the diary by the Abdikov's protagonist become a way of creating a narrative plot - one of the key principles of the postmodern text structure, the dates in Gogol's "Diary..." and their writing exclusively serve as a reception in deploying the themes of the protagonist's madness.

Let us refer to the text vy Gogol (dates formatting and location as in original- $A$. $D$.):

October 3.

... I confess that recently I started sometimes to hear and see things that no one has ever seen before and never heard of. ...

November 12.

... I think the girl took me for a madman, because she was extremely frightened. ...

December 3 .

... I would like to know why am I a titular counsellor? Why a titular counsellor? ...

The year of 2000, the April 43rd.

Today is a day of the greatest celebration! There is a king in Spain. ... And this king is me. ... I do not understand how I could think and imagine that I am titular counsellor. How could I stumble upon this madcap idea? It is good that nobody else did not think at the time of putting me into an asylum. ... (Gogol, 1984, pp. 164-179).

Further, dates got confused not only in their sequence, but also in the writing, and each new distortion is the evidence of the progressing disease of the protagonist, an explicit psychological pathology, which is, apparently, schizophrenia.

The last date in the diary with strange numbers (34 \& 349), with transposed letters in the word "number" and "year", and with downward inverted letters in the word "February" reflects the ultimate madness of the protagonist (Gogol, 1984, p. 185).

It is clear that Gogol's pretext in the novelette "The burning war of the mind" can be sensed not only at the level of the narrative structure of the writing, but also at the level of the problem of madness of the protagonist-narrator, however, if the cause of the disease of the Gogol's protagonist is more social in nature, then for the Abdikov's protagonist, it is more psychological. Intertextual relationship of the novelette by the Kazakh writer with Gogol can found in the following fragment:

"April 20

I am lost, I am unhappy. I fought with own reflection in the mirror... My eyes spilled tears invisible to the world" (Abdikov, 2007). 
A double citation of Russian literature is observed: "tears invisible to the world". Firstly, it is reminiscent of the expression from the "Dead Souls" by N. V. Gogol: "And the strange power destined me to a long time of walking hand in hand with my strange protagonists, of looking at all hugely-bearing life, sweeping it through laughter visible to the world and the tears, invisible, unknown to it!" (Gogol, 1984, p. 277). Second, a clear citation of the title of the narrative by A. P. Chekhov "Tears invisible to the world" (Chekhov, 1983).

This fragment is also interesting that in addition to references to Russian literature, it contains echoes of Western literature. Thus, the archetypal motif of duality (the reflection in the mirror) raises an allusion to "The Picture of Dorian Gray" by Oscar Wilde, echoing, in turn, with the "La Peau de chagrin" by Balzac. Not by chance, one can find in the text the quotation from the writing of the latter: "Balzac was right when he said: "Nothing on the Earth is carried out as fully as the human unhappiness" (Abdikov, 2007). However, we note that the discussion about the European intertext in the novelette by T. Abdikov is upcoming in a separate section of our work.

\section{“The Dream of a Ridiculous Man” by F. M. Dostoyevsky}

The novelette of the "Diary of a Madman" by Gogol has somewhat different description than the story of the protagonist in the narrative by F. M. Dostoyevsky "The Dream of a Ridiculous Man". Here, the narrator does not make it as a diary, but as a narrated story divided into chapters. The topic of madness of the protagonist is depicted very ambiguous. Let us represent it in a shortened form:

"I am a funny person. Now they call me crazy. ... I would laugh with them, ... if I were not so sad, looking at them. It is sad because they do not know the truth, but I know. Oh, how hard it is for one to know the truth!

$\cdots$

I learned the truth last November, namely on the third of November ...

I have no sleep every night until the dawn and it has been that way for a year. ... I sat quietly at the table, pulled out the revolver and put it in front of me. ... I knew too that night I would probably shoot myself ... And I would certainly shoot myself, if it were not that girl.

But if I kill myself, for example, two hours later, then what does the girl mean for me and what do I care then about shame, and all the world?

$\cdots$

It was clear that now the life and the world depend on me.

$\cdots$

Yes, I had this dream, my dream, on the third of November!

$\cdots$

And since then I preach! Also, more than any other I love all that people who are laughing at me. ... I lost words after my dream. At least, all the main words, the most necessary. ... The main thing is to love others as yourself, that is what matters, and that is all, absolutely nothing more is necessary: you will immediately find how to get it made. ... If only all they want, now everything will get made" (Dostoyevsky, 1982, pp. 502-521).

Thus, the alleged insanity of the protagonist by Dostoyevsky is based on the moral, ethical aspect of his experiences. The protagonist calls the truth as a new spiritual understanding of life and human nature, and the truth comes to him through a fantastic dream, the novelette of which is perceived by others as madness.

\section{The "Diary of a Madman" by L. N. Tolstoy}

The same moral aspect as in the narrative by F. M. Dostoyevsky, but with an obsession of the protagonist about his own madness can be found in the "Diary of a Madman" by L. N. Tolstoy:

"1883. October 20. Today they took me to for examination to the provincial government and the opinions were divided. They argued and decided that I am not mad. However, they decided that only because I kept all the forces during the examination, trying not to speak. I did not speak because I'm afraid of asylums; I'm afraid that there they will prevent me from doing my mad affair. They recognized me prone to affects, and something like that, but - in my right mind; they recognized, but I know I'm mad. The doctor prescribed some medication, assuring that if I strictly follow his instructions, the condition will go. Anything that bothers me will go" (Tolstoy, 1982, p. 42).

And in the end: "I said that I cannot buy that mansion because our benefit will be based on the poverty and misery of people. I have said that, and suddenly I was enlightened with the truth of what I had said. What is 
important, is that the truth is in that mugs just want to live as we do, that they are human beings-brothers, sons of the Father, as it is written in the Gospel. ... This was the beginning of my madness. But my complete madness began later, a month later. It started when I went to church, stood the Mass and prayed and listened to, and was pricked. ... Immediately on the porch, I gave away all I had-thirty six roubles, I gave them to the poor, and went home on foot, talking to people" (Tolstoy, 1982, p. 52).

The intertextual connections to deep ideological and philosophical level is obvious between the "Diaries..." by Tolstoy and the "Dreams..." by Dostoyevsky. Formally, starting with the title, the "Diaries..." by Tolstoy are closer to the "Diaries..." by Gogol, given their diary format. It is no coincidence that the madness of the protagonists in the considered writings starts during October and November - in this, in our opinion, one can trace the intertextual relationship: first between the "Dream of a Ridiculous Man" by Dostoyevsky and the "Diary of a Madman" by Gogol, and then-between the "Diary of a Madman" by Tolstoy and the two previous writings.

Next correlation of the novelette "The burning war of the mind" with the writings by Tolstoy sounds directly in the discourse of the writing. So, the doctor-another narrator in the novelette - announcing the diagnosis to the protagonist, says:

"-Do you remember "After the Ball" by Tolstoy? About that colonel who shone in the evening at the ball as the most courteous gallant, prickling all the ladies with excellent manners, and in the morning, on the parade ground, where the penalty was accomplished over a soldier, he distinguished himself as a bloodthirsty beast, a savage executioner. Is not this an example of a split personality?" (Abdikov, 2007)

Thus, the discovery of explicit and encoded by the author intertextual insertions in the novelette "The burning war of the mind", comparing it to the three classic writings of Russian literature, identifying at the narrative level of the intertextual correlation between them, allowed a deeper insight into the problems of the writing by $\mathrm{T}$. Abdikov to include additional meanings, broadcast by intertext.

\subsection{European Classical Intertext in the Novelette}

As we have already noted, one can trace European intertext in the writings by the Kazakh writer. So, after the failed meeting with an imaginary counterpart, the image of Don Quixote arises in the speech of the main narrator: "If he had received my last letter? - suddenly came to my mind. ... "I have not received... not received"-I mumbled. Now everything is clear. And I was all worn out, like the madman who fought with a windmill..." (Abdikov, 2007)

Another narrator also turns to the intertext: important in terms of continuity of the protagonist's moral views-a young doctor auto-trainer, giving an assessment as to the true nature of it:

“- In order to examine your condition fully, I had to get acquainted with your diary...

— All the best and most noble on the Earth have decayed long ago. ... And only thanks to people like you-or perhaps because of you, the only in this world, I still had the time to see the beauty and nobility of our spiritual world. ...

- All of us are werewolves — ... - We are werewolves, and none of us has retained its original angelic purity and innocence. Like Faust, we sold our honour and chastity to the Devil. And only occasionally we hear bitter weeping of infant purity in our souls" (Abdikov, 2007).

An appeal to the "Faust" by Goethe, an allusion to the "baby tears" from "The Brothers Karamazov" by Dostoyevsky, along with the already mentioned writings, translate the text into the philosophical problem of the struggle between the good and the evil, the divine and the demonic, light and dark principles in a man.

An interesting development in this conflict is shown in the attitude of the protagonist and his counterpart to the poetry of Baudelaire. Thus, the narrator-simulacrum says: "Long before us, my friend, there were intelligent people who correctly identified the internal content of the Evil. The French poet Baudelaire sang of it in the book, which is called that way: "The Flowers of Evil". A Japanese writer Akutagawa Ryunoske wrote: "Human life is not worth a single line of Baudelaire" (Abdikov, 2007). However, the main narrator in the conversation with the doctor is indignant: "The most monstrous is that in one of his letters he says that he reads the collection of poems by French poet Baudelaire, who was known as a singer of evil" (Abdikov, 2007).

Special kind of intertextuality on the background of literary citations is the ecphrasis used by the narrator-simulacrum: "Do you remember the picture "Minotaur in the arena" by Picasso? In the midst of it there is a bullring with wounded Minotaur howling like a wolf, with his face to the sky. And someone from behind the shield of the barrier extends the arm to him (apparently a young man not yet intimidated by the generally 
accepted notion of evil), patting the monster on his bull's head, showing him compassion and mercy. And this young man is standing a step closer than all the frenzied crowd of spectators, to the ideals of true Good" (Abdikov, 2007).

Special sound of the problem of the good and the evil in the writing arises in the key written discussion of the main narrator and the narrator-simulacrum, a confrontation between whom can be traced to the level of the philosophical, as we have defined it, intertextuality.

\subsection{Philosophical Intertext in the Novelette}

For the first time this intertext is found in the words of the narrator-simulacrum: "Yes, you know, the Chinese philosophy has the concept of yin and yang, light and dark beginning, heaven and earth, top and bottom. And there is the concept of cycling, when eventually one turns into another. On the gyre of these transitions the world stands ..." (Abdikov, 2007). And then: "Are we happy? I would not say that speaking about me. How can I be happy seeing that much violence and injustice, and being powerless to resist all of these” (Abdikov, 2007). In this episode, again one can hear the motives of Dostoyevsky's writings.

However, the "intertextual authority" for the narrator-simulacrum is Nietzsche: "The greatest era comes when we have the courage to rename all our evil in our best," - said once F. Nietzsche" (Abdikov, 2007).

Nietzsche's philosophy with the idea of the "death of God" and the idea of the Overman was perceived by many of his contemporaries and later as a philosophy of permissiveness, legalizing evil.

The main narrator does not accept this philosophy and opposes his counterpart, also using the philosophical intertext: "P. S. Gottfried Benn: "Hegel, Darwin, Nietzsche - these became the real cause of many deaths of people. Words are more offending than any murder, thoughts are paid for by protagonists and the crowd" (Abdikov, 2007). And: "People deliver themselves the greatest sufferings from the fact that they ignore the simple truth"- the words of your favourite F. Nietzsche" (Abdikov, 2007).

It is generally known about the influence of Nietzsche's philosophy on Dostoyevsky's writing, who put forward his views in opposition to the humanistic ideas of the German philosopher. In this connection, no accidentally, the main narrator, opposing his second "I", quotes the great Russian writer: "Dostoyevsky said: "Where there is no faith-there is no good" (Abdikov, 2007), "You may justify, may not punish, but call evil the evil”-said Dostoyevsky" (Abdikov, 2007).

This main narrator, so to speak, of the "light" essence of the protagonist looks the most intensively filled with the philosophical intertext. The quotes selected by him emphasize the philosophical basis of the story. We list them here: "A wise man once said: There are many ways to do evil, and the way to do no evil is the only one and it is just do not do evil", "When the great Socrates was asked: "What is your difference from the kings?"-he replied: "They are slaves to their passions, and I am their lord", "What is freedom? Well, this is the clear conscience!"- -said Periander of Corinth, a sage who lived seven centuries before our era, And Abay indignantly remarked: "Why is it all malicious villains are considered to be desperately brave?", "We must not fight with the sinner, but with the sin"-said Mahatma Gandhi" (Abdikov, 2007).

Important in the development of philosophical problems in the product are hidden, implicit citations. So, in the words of the doctor-auto-trainer: "The soul of man can only get help from another soul" (Abdikov, 2007) one can guess about the reminiscent of the words of the protagonist from the novelette by Kim A. "Herbalists": "A man can only get relief from a man" (Kim, 1983, p. 90).

The following fragments in the novelette have a lot in common with the writings by A. Kim: "Unfortunately, people are like a cheetah's cubs, but no one can save them from fatal greed,- - except for themselves... For example, by combining the individual "I" into the universal "We". By rejection of the prcinciple "For me". ... Where "I" dominates and there is no "We", there can be no love, no fraternity, nor good understanding" (Abdikov, 2007). And then: "I" cannot win all the rest of the world-and it is defeated. "Life is always a shipwreck", - said Jose Ortega y Gasset. ... "Titanic" sunk. ... That is how they perished, playing the stately hymn of the triumphant "We", which soared on the wings of eternity over the cold ocean abyss. ... This is what happened - in the hour of the great catastrophe and in the face of imminent death—small, pitiful "I" "s united into the great and immortal "We" (Abdikov, 2007).

Let us compare with A. Kim: "We are conceived in tenderness among the stellar worlds, as among the bushes, - in a warm plasma of tenderness of the mother and the father, our blessed parents. ... Rejoice-we are here" (Kim, 1983, p. 286). And then: "And here it is, my concept of man a ... WE, each of us, - is the same phenomenon as the stars. WE fly, WE are immortal and free ...” (Kim, 1983, p. 311). 
"WE" in the philosophy by Kim is a symbol of the merger of separate human "I"'s into a coherent whole, and the whole of humanity is the key to preserving the true essence of a man. This idea is postulated by Abdikov by combining the "own" and the "foreign" words.

Thus, we can say that the novelette "The burning war of the mind" is built on the principle of the "infinite intertextuality" (Ilyin, 1996, p. 50) projecting therein as an important meaning creating element. An appeal to the philosophy and the main problem of the good and the evil in the writing raise the novelette by the Kazakh writer to the philosophical level and put it on par with the canonical examples of the world classics in the centre of which is the same philosophical problem.

\subsection{Mythological Intertext in the Novelette}

Let us note that in addition to the considered citations by the authors, T. Abdikov widely uses mythological intertext, thus saturating the speech main narrator. Mythologemas from different mythologies turn to be included in it. We prove this by the text.

Classical mythology: "Of course, one can assume that one day the sun will go out, and human life on earth will disappear, as if it never existed, and the thinking of a human being, the miraculous child of the universe, will sink into oblivion ..." (Abdikov, 2007). And: "Only God knows what will be the end of humanity. ... Perhaps, the story of Noah will repeat indeed — and the Flood will happen" (Abdikov, 2007).

Biblical mythology: "Every grain of the good or evil arises on the ground first as a word" (Abdikov, 2007). And: "It means that the dead are considered to be defeated. However, did the defeat of Jesus Christ, who was killed by his enemies with incredible cruelty, then become the greatest victory for humanity?" (Abdikov, 2007)

Muslim mythology: "Perhaps mankind was saved from fatal depravity and spiritual decay by religion. And if it was unable to defeat the Iblis, the devil of temptation, completely, then, at least, the devil was exposed and cursed with condemnation" (Abdikov, 2007). Iblis is the devil in the Muslim mythology.

Along with this mythonim, the main narrator mentions the names of Nero, Caligula, who historically became the archetypes of evil and tyranny: "According to this logic, the Roman caesars Nero, Caligula and others ...,- will be the freest people in human history" (Abdikov, 2007).

These myths contain a rich spiritual and cultural-historical experience of humanity, related to the theme of the Apocalypse and the rebirth of a man. Due to their use in the background of all of the intertextuality in the writings, the author is trying to solve the perennial problem of the meaning of a human's life and the role of the good and the evil in it.

\subsection{National Intertext in the Novelette}

National, Kazakh, intertext in the novelette is presented by the names of Abay and Mukagali Makatayev. It is noteworthy that the author puts Abay in the number of the great humanists, as described above. Introduction of intertextuality in this case plays a dual role. First, attaching Abay to the great philosophers, the author points out that the domestic, national media had outstanding thinkers, who were concerned with the same problems as the world famous philosophers. Secondly, the author as if calls to turn to private, national, folk sources for answers to many questions that concern the mankind.

The protagonist of the writing, declaring the absolute value of the good, cannot find those answers for himself, and learn about their opposite effect, manifesting the triumph of evil, loses the sense of own life. The only way to rescue his true "I" from the other "I" he sees in the suicide: "Well, I still had to take my hands in your destiny. They say, one cannot escape it" (Abdikov, 2007).

These are the concluding words of the main narrator who is not represented as an entry in his diary, but as his inner monologue, as if overheard by someone. The protagonist remains faithful to the ideals of the good to the last, which is proved by the ending of his speech with the poem by M. Makatayev:

("I have a cherished dream: If one day the Flood of the Goodness will rush on the Earth

I will rake in all the evil into my arms and it will die with me.... Happy worth me to become a nameless victim, the one, that having taken the spear of guilt of the human's malices to my chest, with the soul in glee, the one who will release the world from the burden of sins. Go and bring me your grieve sand lade my sleazy luggage with your evil junk! And if it is all to die together with me - I will be happy to die even today!...Let me go to my final journey — and please, people, do not ever seek for the Evil. Live without it! And please never knock on my narrow coffin with evil") (Abdikov, 2007).

The poem by the outstanding Kazakh poet plays a special role in the writing. It is a kind of an answer to the question sounding in the epigraph to the novel. If Shakespeare's Hamlet asks: 
To be, or not to be, that is the question-

Whether "tis Nobler in the mind to suffer

The Slings and Arrows of outrageous Fortune,

Or to take Arms against a Sea of troubles,

And by opposing, end them? To die, to sleep...(Abdikov, 2007),

then the persona by Makatayev firmly answers, that he is ready to die to liberate the humanity from evil forever.

Thus, the author creates a kind of poetic ring that is both intertextual ring in the writing, due to which there is a link between the world of literature and the national literature of Kazakhstan. Moreover, the author emphasizes the importance of the problematics raised in the writing, both globally and purely nationally.

Finishing the main part of his writing with poem by his compatriot, Abdikov rightly raises M. Makatayev to the level of the great writers of world literature, paying tribute to the national poet and showing the versatility and urgency of the problem of good and evil in the modern world.

The departure or just an attempt to depart by the protagonist of the narrative-a postmodern text gives no ambiguous endings - perhaps, did not prove the victory of good in an absolute sense, but excluded the possibility of victory of evil in itself. By that, the author postulates the priority of good over evil, with all the ambivalence of these concepts.

The narrative ring is closed by the primary narrator, who introduced the protagonist diary to us. His concluding words, following the postmodern tradition, contain a new intrigue, giving the reader the options to interpret the ending of the writing, up to the conclusion on whether the author is the primary narrator of the diary? "Thus ends the diary - with one of the darkest verses by the famous poet M. Makatayev.

...I do not know the further destiny of the defenceless, uncompromising man for whom moral purity has become synonymous to God. If he miraculously survived, managed to stay alive, then I sincerely wish him luck. ...

And if he is no longer among the living ones, then ... all the will of God. May he rest in peace!

Amen!" (Abdikov, 2007)

\section{Conclusion}

Thus, we conclude that the narrative peculiarities of the novelette "The burning war of the mind" allow the author to express own, original vision of the problem of good and evil, philosophical in nature. The special design it gets in the writing through an extensive intertextuality, which becomes a narrative strategy of a game with the reader, the manipulation of their reception. T. Abdikov, including motifs, images and responsive works of the world classics in the context of his novel, "internationalizes", using the definition by L. V. Safronova (Safronova, 2006, p. 27), the story of the writing, expands, deepens and fills in with additional meanings, creating synergies in the semantics of the text. The gathering of these meanings by the reader is the author's intention. In addition, a rich intertextual background used in the novelette builds, as we have already said, the writing by T. Abdikov into the "great intertext" of world literature.

At the same time, we shall note that the intertextual connections identified in the novelette "The burning war of the mind" are not indisputable and complete, because they are limited to our "citation consciousness" and therefore can be refuted or supplemented by other researchers, with a different "citation consciousness".

\section{References}

Abdikov, T. (2007). The burning war of the mind. (Druzhba narodov, No. 6, Translated by A. Kim) [Online]. Retrieved January 30, 2015, from http://magazines.russ.ru/druzhba/2007/6/ab6.html

Bahtin, M. M. (1994). The problems of the works by Dostoyevsky (amended) (5th ed., p. 510). Kiev: NEXT.

Barthes, R. (1973). Texte. Encyclopaedia universalis (p. 78).

Chekhov, A. P. (1983). Tears invisible to the world. Full thirty-book set of writings and letters. In Eighteen-book set (Vol. 3, pp. 1884-1885). Moscow: Nauka.

Dostoyevsky, F. M. (1982). The Dream of a Ridiculous Man. In Twelve-book set. (Vol. 12, pp. 502-521). Moscow: Pravda.

Gogol, N. V. (1984). Dead Souls. In Two-book set of selected works (Vol. 2, p. 495). Moscow: Hudozhestvennaya literatura.

Gogol, N. V. (1984). The Diary of a Madman. In Eight-book set (Vol. 3, pp. 164-185). Moscow: Pravda. 
Retrieved February 3, 2015, from http://cyberleninka.ru/article/n /kommunikativnye-strategii-ya-narrativa-na-materiale-proizvedeniy-sovremennoy-russkoy-literatury

Ilyin, I. P. (1996). Post-structuralism. In Deconstructionism Post-modernism (p. 220). Moscow: Intrada.

Kim, A. (1983). Herbalists. In Narrative stories (p. 576). Moscow.

Kovaliov, O. A. (2009). Narrative strategies in the literature (based on the works by F. M. Dostoyevsky): Monograph (p. 198). Barnaul: Publishing House of the Altai University.

Safronova, L. V. (2006). Postmodern literature and contemporary literary in Kazakhstan: Textbook (p. 96). Almaty: KazNPU n. a. Abay.

Schmid, W. (2008). Narratology (2nd ed., rev. and amended, p. 304). Moscow: Languages of the Slavic culture.

Shunikov, V. L. (2006). Communication strategies of "I"-Narrative (based on the writings of modern Russian literature) [Online].

Tolstoy, L. N. (1982). The Diary of a Madman. In Twenty two-book set (Vol. 12, p. 457). Moscow: Hudozhestvennaya literatura.

Tsurganova, E. A. (1990). The modern novel and the peculiarities of the literature of the second half of the XX century (pp. 3-24). Introduction. Modern novel. The experience of exploring. Moscow: Nauka.

Tyupa, V. I. (2011). Narrative strategy of a novel. New philology bulletin, 3(18).

Zhilicheva, G. A. (2013). Narrative strategies in the genre structure of the novel (based on Russian prose of 1920s-1950s): Monograph (p. 317). Novosibirsk: NSPU.

\section{Copyrights}

Copyright for this article is retained by the author(s), with first publication rights granted to the journal.

This is an open-access article distributed under the terms and conditions of the Creative Commons Attribution license (http://creativecommons.org/licenses/by/3.0/). 